\title{
Pengaruh Dukungan Spritual terhadap Tingkat Kecemasan pada Pasien Pre-Operasi
}

\author{
El Rahmayati ${ }^{1}$, Ruth Novelina Silaban ${ }^{2}$, Siti Fatonah ${ }^{3}$ \\ 1,2,3 Jurusan Keperawatan, Politeknik Kesehatan Tanjungkarang, Indonesia \\ Email: elrahmayati@poltekkes-tjk.ac.id
}

\begin{abstract}
The Effect of Spiritual Support on Anxiety Levels of Pre-operative Patients. Anxiety is an emotional response to the subjective judgment of individuals, influenced by the unconscious and not specifically known to cause. Based on data from the World Health Organization (WHO) in 2007, the United States analyzed data from 35,539 surgical clients treated in the intensive care unit from 2003 to 2006, of which 2,473 clients (7\%) experienced anxiety conditions. The results of Masood Jawaid's research, et al.(2006) found that average respondents in a state of moderate anxiety as much as 57.65 . The purpose of this study was to determine the effect of spiritual support on anxiety levels in pre-operative patients. This study was Quasi-Experiment with one group pretest-posttest design, sampling was using purposive sampling technique. Sample amounted to 16 respondents, population amounted to 325 patients. The Data collection tool was using a questionnaire sheet. The statistical test was using Wilcoxon test. The average yield of anxiety prior to therapy spiritual support was 49.88 , with a standard deviation of 6.449 . While the average anxiety after the therapy spiritual support was 46.81 with a standard deviation of 6.002 . The statistical test result showed that $\mathrm{p}$-value $=0.001$, there was an effect of a spiritual support therapeutic to the level of anxiety of patients pre-operation at Imanuel Hospital Lampung Year 2017. This study suggested therapy for spiritual support as nursing care in patients who experience anxiety.
\end{abstract}

Keywords: Anxiety, Spiritual support, Pre-operation

\begin{abstract}
Abstrak: Pengaruh Dukungan Spritual terhadap Tingkat Kecemasan pada Pasien PreOperasi. Kecemasan merupakan respon emosional terhadap penilaian individu bersifat subjektif, yang dipengaruhi alam bawah sadar dan tidak diketahui secara khusus penyebabnya. Berdasarkan data World Health Organization (WHO) pada tahun 2007, Amerika Serikat menganalisis data dari 35.539 klien bedah dirawat di unit perawatan intensif tahun 2003 sampai dengan 2006, sebanyak 2.473 klien (7\%) mengalami kondisi kecemasan. Hasil penelitian Masood Jawaid, et al. (2006) didapatkan bahwa rata-rata responden dalam keadaan cemas sedang sebanyak 57,65. Tujuan penelitian ini untuk mengetahui pengaruh dukungan spritual terhadap tingkat kecemasan pada pasien pre-operasi. Rancangan penelitian ini menggunakan Quasi Eksperimen dengan desain penelitian one group pretest-posttest, pengambilan sampel menggunakan teknik Purposive Sampling. Sampel berjumlah 16 responden, populasi berjumlah 325 pasien. Alat Pengumpulan data menggunakan lembar kuesioner. Uji statistik yang digunakan adalah uji Wilcoxon. Hasil ratarata kecemasan sebelum terapi dukungan spritual 49,88, dengan standar deviasi 6,449. Sedangkan rata-rata kecemasan sesudah terapi dukungan spritual46.81 dengan standar deviasi 6,002. Hasil uji statistik didapatkan nilai $p=0.001$, maka dapat disimpulkan bahwa ada pengaruh terapi dukungan spritual terhadap tingkat kecemasan pada pasien pre-operasi di RS Imanuel Provinsi Lampung Tahun 2017. Dari hasil penelitian disarankan terapi dukungan spritual sebagai asuhan keperawatan pada pasien yang mengalami kecemasan.
\end{abstract}

Kata kunci: Kecemasan, Dukungan spiritual, Pre-operasi

Menurut World Health Organization (WHO) dalam Sartika (2013), jumlah pasien dengan tindakan operasi mencapai angka peningkatan yang sangat signifikan dari tahun ke tahun. Tercatat di tahun 2011 terdapat 140 juta pasien di seluruh rumah sakit di dunia, sedangkan pada tahun 2012 data mengalami peningkatan sebesar 148 juta jiwa. Tindakan operasi di Indonesia pada tahun 2012 mencapai 1,2 juta jiwa. Berdasarkan data dari RS IMANUEL Provinsi Lampung didapatkan data bahwa dari Juli 2016 sampai bulan Desember 2016 tercatat sebanyak 2.292 pasien yang menjalani tindakan pembedahan. 
Pembedahan terdiri dari tiga fase: preoperatif, intra-operatif, dan pasca-operatif. Fase pre-operatif dimulai saat keputusan untuk melakukan pembedahan dibuat dan berakhir ketika klien dipindahkan ke meja operasi. Pembedahan adalah pengalaman yang menyebabkan stres dan perubahan fisik serta fisiologik (Kozier, 2009). Kecemasan adalah satu kondisi kegelisahan mental, keprihatinan, ketakutan, firasat atau perasaan putus asa karena ancaman yang akan terjadi atau ancaman antisipasi yang tidak dapat diidentifikasi terhadap diri sendiri atau terhadap hubungan yang bermakna. Pengertian lain cemas adalah suatu keadaan yang membuat seseorang yang tidak nyaman dan terbagi dalam tingkatan. Jadi, cemas berkaitan dengan perasaan yang tidak pasti dan tidak berdaya (Kusumawati dan Hartono, 2010). Kecemasan merupakan istilah yang sangat akrab dengan kehidupan sehari-hari yang menggambarkan keadaan khwatir, gelisah, takut tidak tentram disertai berbagai keluhan fisik (Dalami, et al, 2009). Kecemasan pada pasien yang akan dilakukan operasi biasanya berhubungan dengan segala macam prosedur asing yang harus dijalani pasien dan juga ancaman terhadap keselamatan jiwa akibat prosedur pembedahan dan tindakan pembiusan. Pasien yang mengalami kecemasan menunjukan gejala mudah tersinggung, susah tidur, gelisah, lesu, mudah menangis dan tidur tidak nyenyak (Stuart, 2006).

Data World Health Organization (WHO) tahun 2007 menyatakan bahwa $25,1 \%$ atau 8.922 orang klien post operasi yang dirawat di unit perawatan intensif mengalami gangguan kejiwaan dan $7 \%$ atau 2.473 orang klien mengalami kecemasan. Hasil penelitian lain di Civil Hospital Karachi, Pakistan, yang dilakukan oleh Masood Jawaid, et al (2006), mengatakan bahwa $57,65 \%$ pasien pre-operasi mengalami kecemasan. Dari penelitian tersebut disimpulkan bahwa sebagian besar pasien pre-operasi mengalami kecemasan karena takut dengan pembiusan dan anastesi.

Menurut Jong (1997) dikutip dari Agusnawati (2013), mengungkapkan bahwa kecemasan timbul pada pasien dipengaruhi oleh berbagai faktor antara lain cemas berkaitan dengan penyakitnya, pengobatan dan pemeriksaan diagnosis yang dihadapi. Pasien yang akan mengalami pembedahan akan merasa cemas disebabkan karena faktor-faktor diagnosis keganasan, anastesi, sakaratul maut, nyeri, perubahan penampilan, keterbatasan permanen. Selain itu pasien menghadapi pembedahan dilingkupi oleh rasa takut yaitu takut akan ketidaktahuan, kematian, takut dengan anastesi, kanker, kekhawatiran kehilangan waktu kerja, kehilangan pekerjaan, tanggung jawab mendukung keluarga, dan ancaman ketidakmampuan permanen. Perasaan takut dioperasi timbul karena takut menghadapi kematian dan tidak bisa bangun lagi setelah dioperasi.

Menurut Rozalino (2009) dikutip dari Agusnawati (2013), salah satu upayanya dalam intervesi keperawatan untuk mencegah ansietas adalah dengan terapi spiritual. Terapi spiritual merupakan suatu pengobatan alternatif dengan cara pendekatan keagamaan melalui doa dan dzikir yang merupakan unsur penyembuhan penyakit atau sebagai psikoterapeutik yang mendalam, bertujuan untuk membangkitkan rasa percaya diri dan optimisme yang paling penting selain obat dan tindakan medik.

Menurut Alexis Carrel dalam bukunya berjudul Pray (Doa) tentang pengalamannya dalam mengobati pasien. Banyak diantara pasiennya memperoleh kesembuhan dengan jalan berdoa. Doa adalah suatu gejala keagamaan yang paling agung bagi manusia karena pada saat itu jiwa manusia terbang menuju Tuhannya. Kalaupun apa yang dimohonkan tidak sepenuhnya terpenuhi, namun dengan doa tersebut seseorang telah hidup dalam suasana optimisme, harapan dan ketenangan batin.

Berdasarkan data pada bulan Februari 2017 yang diperoleh dari RS Imanuel Provinsi Lampung 435 orang pasien yang menjalani pembedahan.Hasil wawancara dengan perawat di ruang bedah wanita dan ruang bedah pria didapatkan data bahwa dalam menangani kecemasan pasien pre-operasi perawat memberikan pendidikan kesehatan mengenai informasi tentang prosedur pembedahan yang akan dilakukan dan mengajarkan teknik relaksasi nafas dalam. Hasil wawancara dengan seoarang pendeta di RS Imanuel didapatkan data bahwa tidak ada SOP tentang terapi dukungan spritual di rumah sakit tersebut, namun di ruangan bila ada pasien yang ingin di doakan baik sebelum menjalankan operasi maupun tidak maka di doakan oleh pendeta rumah sakit tersebut. Doa yang dilakukan oleh pendeta merupakan suatu bentuk terapi kepada pasien yang berupa bantuan atau bimbingan doa kepada agama Kristen. Adapun tujuan dari penelitian ini adalah untuk mengetahui pengaruh dukungan spritual terhadap penurunan tingkat kecemasan pada klien preoperasi di RS Imanuel Provinsi Lampung. 


\section{METODE}

Penelitian ini menggunakan metode Quasi eksperimen, dengan rancangan One Group Pretest Post-test. Populasi dalam penelitian adalah pasien yang akan menjalani operasi elektif dan mengalami kecemasan pre-operasi di ruang bedah RS Imanuel Provinsi Lampung Tahun 2017 dengan besar sampel 16 responden.

Instrumen yang digunakan dalam terapi spiritual adalah menggunakan SOP terapi spiritual dengan cara memberikan terapi spiritual yang sesuai dengan SOP yang telah terstandar. Sedangkan untuk kecemasan pasien menggunakan alat ukur kuesioner ZSRAS (Zung Self Rating Anxiety Scale).

\section{HASIL}

\begin{tabular}{|c|c|c|c|c|}
\hline \multirow{2}{*}{\multicolumn{5}{|c|}{ Tabel 1. Perbedaan $\quad$ Rata-Rata }} \\
\hline & & $\begin{array}{l}\text { Rata-R } \\
\text { elum }\end{array}$ & Dan & $\begin{array}{l}\text { Skor } \\
\text { esudah }\end{array}$ \\
\hline $\begin{array}{l}\text { Terap } \\
\text { Pasien }\end{array}$ & $\begin{array}{l}\text { Dukun } \\
\text { re-Ope }\end{array}$ & $\begin{array}{ll}\text { an } & S \\
\text { asi } & \end{array}$ & ritual & Pada \\
\hline Variabel & Mean & SD & $\begin{array}{c}p- \\
\text { value }\end{array}$ & n \\
\hline $\begin{array}{l}\text { Kecemasan } \\
\text { sebelum terapi } \\
\text { dukungan } \\
\text { spritual }\end{array}$ & 49.88 & 6.449 & & \\
\hline $\begin{array}{l}\text { Kecemasan } \\
\text { setelah terapi } \\
\text { dukungan } \\
\text { spritual }\end{array}$ & 46.81 & 6.002 & 0,001 & 16 \\
\hline
\end{tabular}

Berdasarkan tabel 1 dapat disimpulkan bahwa rata-rata skor indeks kecemasan preoperasi sebelum diberikan terapi dukungan spritual adalah 49.88. Pada pengukuran rata-rata skor kecemasan setelah diberikan terapi dukungan spritual didapatkan rata-rata kecemasan 46.81, nilai perbedaan mean antara kecemasan sebelum dan sesudah diberikan terapi dukungan spritual adalah 3.07. Hasil uji statistik dengan uji Wilcoxon Signed Ranks Test didapat hasil $p$-value sebesar $(0,001)<\alpha(0,05)$, hal ini menunjukkan ha diterima yang artinya terapi dukungan spritual memiliki pengaruh dalam menurunkan tingkat kecemasan pada pasien preoperasi.

\section{PEMBAHASAN}

Berdasarkan hasil penelitian ini diperoleh data rata-rata skor kecemasan responden sebelum dilakukan terapi dukungan spritual dengan hasil 49,88, rata-rata skor kecemasan responden setelah dilakukan terapi dukungan spiritual dengan hasil 46,81. Terdapat penurunan rata-rata skor sebesar 3,07. Hasil uji statistik dengan uji Wilcoxon Signed Ranks Test didapat hasil p-value sebesar $(0,001)<\alpha(0,05)$, hal ini menunjukkan ha diterima yang artinya terapi dukungan spritual memiliki pengaruh dalam menurunkan tingkat kecemasan pada pasien pre-operasi.

Menurut Taufik (2006) dalam Perdana (2012), menyatakan bahwa jenis bimbingan spritual berupa bimbingan doa akan menimbulkan rasa percaya diri, rasa optimisme (harapan kesembuhan), mendatangkan ketenangan, damai, dan merasakan kehadiran Tuhan Yang Maha Esa.

Menurut Smeltzer \& Bere (2002) dalam Setyaningrum (2015), proses penurunan kecemasan adalah sebagai berikut, seseorang mengalami kecemasan akan mengaktifkan saraf otonom (simpatis dan parasimpatis). Saraf simpatis akan mengaktifkan proses tubuh, sedangkan sistem saraf parasmpatis akan meminimalkan respon tubuh yang dapat muncul ketika seseorang cemas. Bila korteks otak menerima rangsangan berupa cemas akan dikirim melalui saraf simpatis ke kelenjar adrenal yang akan melepaskan adrenalin atau epinefrin sehingga efeknya antara lain nafas menjadi lebih dalam, nadi meningkat.

Hasil penelitian ini sejalan dengan penelitian sebelumnya yang dilakukan oleh Perdana (2012), pengaruh bimbingan spritual terhadap tingkat kecemasan pada pasien preoperasi di rawat inap RSUD Kajen Kabupaten Pekalongan ( $p$-value $=0,000<0,05)$.

Hasil penelitian ini juga sejalan dengan hasil penelitian Simbolon (2015), pengaruh terapi musik terhadap tingkat kecemasan pada pasien pre-operasi di rawat bedah RS Santa Elisabeth Medan ( $p$-value $=0,000<0,05)$.

Hasil penelitian ini juga sejalan dengan hasil penelitian Sawitri (2016), pengaruh terapi psikospritual terhadap tingkat kecemasan pada pasien pre-operasi di Ruang Melati III RSUP Dr.Soeradji Tirtonegoro Klaten ( $p$ value $=0,000<0,05$ ).

Berdasarkan hasi analisis, beraneka ragam agama dan kepercayaan. Seseorang yang memiliki keyakinan akan keberadaan Tuhan Yang Maha Kuasa memiliki kekuatan, pengharapan untuk meminta kesembuhan, keselamatan dan perlindungan melalui doa. Terapi dukungan spritual memberikan rasa yang lebih tenang dan rileks untuk seseorang yang sedang membutuhkan pertolongan. Menurut peneliti, terapi dukungan spritual dapat diberikan kepada pasien pre-operasi untuk menurunkan 
tingkat kecemasan. Saat ini rumah sakit belum terprogram, dengan hasil perbedaan yang cukup baik diharapkan RS Imanuel dapat menyusun program untuk melaksanan terapi spritual sebagai bagian dari asuhan keperawatan. Jika melihat dari analisa bivariat dapat disimpulkan terdapat pengaruh terapi dukungan spritual terhadap tingkat kecemasan pada pasien pre-operasi di RS Imanuel Provinsi Lampung.

Terapi dukungan spritual ini merupakan bentuk asuhan keperawatan yang holistik. Dalam prinsip atau pelaksanaan terapi dukungan spritual menunjukan prilaku caring yang dapat memberikan ketenangan, kenyamanan bagi klien sehingga mendekatkan hubungan terapeutik perawat dan klien. Terapi dukungan spritual merupakan salah satu dari komplementer. Sehingga jika ditinjau dari legal aspek pelaksanaan terapi dukungan spritual ini, bahwasanya perawat diperkenankan menerapkan terapi komplementer sebagaimana telah diatur dalam UU No. 38 Tahun 2014 tentang Keperawatan pada pasal 30 ayat (2) huruf m menyatakan; Dalam menjalankan tugas sebagai pemberi Asuhan Keperawatan di bidang upaya kesehatan masyarakat, Perawat berwenang melakukan penatalaksanaan Keperawatan komplementer dan alternatif. Dalam penjelasannya pasal 30 ayat (2) huruf $m$ tersebut adalah melakukan penatalaksanaan keperawatan komplementer dan alternatif merupakan bagian dari penyelenggaraan praktik keperawatan dengan memasukan atau mengintegrasikan terapi komplementer dan alternatif dalam pelaksanaan asuhan keperawatan. Rumah Sakit menetapkan kriteria orang orang-orang yang akan melakukan terapi dukungan spritual untuk pasien yang mengalami kecemasan pre-operasi. Sehingga perawat berpeluang mempelajari berbagai macam terapi komplementer serta dukungan spritual direkomendasikan agar dapat diterapkan dan di kombinasikan dengan terapi komplementer lain sebagai terapi pendamping atau sebagai bagian dari intervensi keperawatan dalam pemberian asuhan keperawatan pada pasien yang mengalami kecemasan pre-operasi.

\section{SIMPULAN}

Berdasarkan hasil peneltian yang dilakukan penulis di RS Imanuel Provinsi Lampung tahun 2017, dapat disimpulkan bahwa:

1. Nilai rata-rata skor kecemasan responden sebelum terapi dukungan spritual adalah 49,88 di RS Imanuel Provinsi Lampung.

2. Nilai rata-rata skor kecemasan responden setelah terapi dukungan spritual adalah 46,81 di RS Imanuel Provinsi Lampung.

3. Ada perbedaan antara skor kecemasan sebelum terapi dukungan spritual adalah 49,88 dan setelah terapi dukungan spritual adalah 46,81 pada pasien pre-operasi di RS Imanuel Provinsi Lampung.

\section{SARAN}

1. Hasil penelitian ini dapat diterapkan oleh rumah sakit dalam mempersiapkan pasien yang mengalami kecemasan dalam menghadapi tindakan operasi.

2. Menyusun SOP untuk pelaksanaan terapi dukungan spiritual.

3. Menetapkan kriteria orang yang memenuhi syarat untuk dijadikan sebagai terapis dukungan spiritual.

\section{DAFTAR PUSTAKA}

Agusnawati. 2013. Pengaruh terapi spiritual terhadap tingkat ansietas pasien preoperasi elektif di Ruang Bedah RSUD Dr. H. Bob Bazar, SKM Kalianda. [Skripsi]. Universitas Malahayati

Dalami, Ermawati, et al. 2009. Asuhan Keperawatan Jiwa dengan Masalah Psikososial. Jakarta: TIM.

Farida, Kusumawati \& Yudin Hartono. 2010. Buku Ajar Keperawatan Jiwa. Jakarta: Salemba Medika.

Kozier. 2009. Buku ajar fundamental keperawatan konsep, proses \& praktik vol 2. Edisi 7. Jakarta: EGC.

Perdana, M., \& Niswah, Z. 2012. Pengaruh Bimbingan Spiritual Terhadap Tingkat Kecemasan Pada Pasien Pre Operatif Di Ruang Rawat Inap RSUD Kajen Kabupaten Pekalongan. [Skripsi]. STIKES Muhammadiyah Pekajangan. Tidak dipublikasikan.

Sawitri, E. 2016. Pengaruh Terapi Psikospritual Terhadap Tingkat Kecemasan Pada Pasien Pre Operasi Di Ruang Melati III RSUP Dr Soeradji Tritonegoro Klaten. Jurnal Ilmu Keperawatan. Journal of Nursing Science, 9(1).

http://ejournal.stikesmukla.ac.id/index.php/ 
triage/article/download/193/191 (Diakses pada 21 September 2017).

Simbolon, Pomarida. 2015. Pengaruh terapi musik terhadap tingkat kecemasan pada pasien pre operasi di Ruang Rawat Bedah Rumah Sakit Santa Elisabeth Medan. Jurnal Stikes Elisabeth Medan. http://jurnal.stikeselisabethmedan.ac.id/ind ex.php/elisabeth/issue/download/22/5+\&cd $=1 \&$ hl $=\mathrm{id} \& \mathrm{ct}=\mathrm{clnk}$ (Diakses pada 5 Juli 2015).

Stuart, Gail W. 2006. Buku Saku Keperawatan Jiwa. Edisi 5. Jakarta: EGC. 